\title{
SULPHATES IN COMPLETELY RECYCLABLE CONCRETE AND THEIR EFFECT ON THE CLINKER MINERALOGY
}

\author{
Mieke De Schepper ${ }^{1}$, Eleni C. Arvaniti ${ }^{2}$, Klaartje De Buysser ${ }^{3}$, Isabel Van Driessche ${ }^{4}$, Nele De Belie ${ }^{5}$ \\ ${ }^{1}$ Magnel Laboratory for Concrete Research, Department of Structural Engineering, Ghent University, Ghent, Belgium \\ ${ }^{2}$ Magnel Laboratory for Concrete Research, Department of Structural Engineering, Ghent University, Ghent, Belgium \\ ${ }^{3}$ SCRiPTS, Department of Inorganic and Physical Chemistry, Ghent University, Ghent, Belgium \\ ${ }^{4}$ SCRiPTS, Department of Inorganic and Physical Chemistry, Ghent University, Ghent, Belgium \\ ${ }^{5}$ Magnel Laboratory for Concrete Research, Department of Structural Engineering, Ghent University, Ghent, Belgium
}

\begin{abstract}
Although concrete is a durable material, it has a big impact on the environment due to its high production volumes. This impact is mostly related to the consumption of virgin raw materials, the production of waste and the emission of carbon dioxide. To optimize the recycling opportunities of concrete, Completely Recyclable Concrete is designed as a raw material for clinker production, without the need for ingredient adjustments. However, CRC concrete constructions may be exposed to environments rich in chlorides, sulphates and other ions, affecting the clinkering process of CRC rubble. Therefore, it is important to know the effect of these ions on the mineralogy of CRC clinker. In this study the effect of sulphate additions to CRC raw meals on the final clinker mineralogy was studied by XRD/Rietveld analysis. It was found that an increasing sulphate content stimulates the formation of $\mathrm{CaO}$ containing sulphates such as calcium langbeinite and anhydrite. Additionally $\mathrm{SO}_{3}$ was found to stabilize belite at the expense of alite.
\end{abstract}

Keywords: Cement clinkering, Sulphates, X-ray diffraction

\section{INTRODUCTION}

Since the first industrial cement was produced in the middle of the $19^{\text {th }}$ century, concrete has become the most popular building material. Although it is a durable material, concrete has a big impact on the environment due to its high production volumes. Besides the use and the generation of enormous amounts of natural resources and waste respectively, the impact on global warming should equally be considered. The cement industry is estimated to emit about $5-7 \%$ of the global $\mathrm{CO}_{2}$ emissions. For these reasons many studies in the field of concrete research focus on the recycling of solid waste in concrete. Solid waste can be used as concrete aggregate (e.g. slags, glass, concrete, ...), cementitious binder (e.g. slags, bottom and fly ash, silica fume, ...) or raw material for clinker production (e.g. slags, bottom or fly ash, mining waste, refinery residues, ...). Most of the recycling opportunities, however, often arise from the search for new synergies between usually unrelated partners. Also, recycled products still suffer from a low acceptability by a lack of trust in the quality of these products and in some cases by the higher cost of recycled materials compared to natural materials.

To take recycling to a higher level, products could be 'designed for reincarnation' according to the Cradle-toCradle concept promoted by McDonough and Braungart. Applying this idea on the production of concrete, it is easy to notice that the raw materials used for concrete and cement production share common base components. Hence the idea emerged to design a Completely Recyclable Concrete (CRC) which can be used as the only ingredient for cement production after its service life. In order to make CRC a valuable technical resource for cement production, without need for ingredient adjustments, the concrete mixture should be chemically equivalent to a traditional cement raw meal. The primary ingredient for CRC is limestone aggregate as a source for $\mathrm{CaO}$, the main ingredient for Portland cement production. Besides natural raw materials, such as limestone and porphyry aggregate, industrial by-products like fly ash and copper slag are preferably used for CRC production.

The degradation of a CRC structure can affect the future clinkering process of the CRC rubble and thus its regenerated clinker. Carbonation will mainly affect the $\mathrm{CO}_{2}$ emissions during the production of the regenerated cement. Since this $\mathrm{CO}_{2}$ was captured from the atmosphere during the life cycle of concrete, this additional $\mathrm{CO}_{2}$ release can be considered neutral in a life cycle assessment. However, the effect of the permeation of acids and salts (alkalis, $\mathrm{Cl}^{-}$, $\mathrm{SO}_{4}{ }^{2-}, \mathrm{Mg}^{2+}$ ) in $\mathrm{CRC}$ on the regenerated cement, should be considered differently. Their effect may be positive or negative, depending on the concentration. For all of these components, proper dilution might thus be required to avoid problems during the clinkering process or in the final cement. In this study the effect of sulphate additions on the clinker mineralogy was assessed using XRD/Rietveld analysis.

\section{THEORETICAL BACKGROUND}

The effect of sulphur on the clinkering process is related to the alkalis present, and both will participate in cycles of evaporation and condensation in the clinker kiln [1]. The 
sulphates, originating from the raw materials or the fuels, introduced in the clinkering process must eventually appear in one of the three output streams: clinker, cement kiln dust or gaseous emissions. As for the chlorides, also sulphate may be retained in the kiln as annular deposits, and contribute to the formation of kiln rings, interrupting the normal downslope flow of the cement raw meal.

Alkalis affect the clinkering process by modifying the physicochemical properties of the melt, and may have an adverse effect on the phase composition of the clinker [2]. In the presence of sulphur, the volatility of the alkali during clinker formation is reduced. The alkali sulphates hereby present in the melt can decrease its viscosity, but even a small stoichiometric excess of alkali oxide over $\mathrm{SO}_{3}$ increases it. A low viscosity of the melt is favoured as it stimulates the formation of alite by accelerating dissolution and diffusion through the liquid of lime and belite.

When the molar $\mathrm{SO}_{3} /\left(\mathrm{K}_{2} \mathrm{O}+\mathrm{Na}_{2} \mathrm{O}\right)$ are in balance, almost all of the sulphur and alkalis are present in the clinker as alkali sulphates (arcanite $\left(\mathrm{K}_{2} \mathrm{SO}_{4}\right)$, aphthitalite $\left(\mathrm{K}_{3} \mathrm{Na}\left(\mathrm{SO}_{4}\right)_{2}\right.$, thenardite $\left.\left(\mathrm{Na}_{2} \mathrm{SO}_{4}\right)\right)$, and very little of the sulphate or alkalis can be incorporated in the clinker phases. A separated liquid phase is formed in the burning zone, which is immiscible with the normal aluminate/ferrite liquid phase [1]. If alkalis are present in the excess of sulphate, the excess $\mathrm{Na}_{2} \mathrm{O}$ and $\mathrm{K}_{2} \mathrm{O}$ is available to be incorporated in the clinker phases, particularly in $\mathrm{C}_{3} \mathrm{~A}$. The latter results in the formation of so called 'alkali aluminate', or orthorhombic $\mathrm{C}_{3} \mathrm{~A}$, which is more reactive compared to cubic $\mathrm{C}_{3} \mathrm{~A}$ and can result in faster setting times. If there is an excess of sulphate present, potassium sulphate will associate with calcium sulphate to form calcium langbeinite. The occurrence of anhydrite in the cement clinker is related to both the $\mathrm{SO}_{3}$ and alkali (especially $\mathrm{K}_{2} \mathrm{O}$ ) content.

\section{MATERIALS \& METHODS}

\subsection{Mix Design}

Calcium sulphate was added to the CRC mixtures to simulate the effect on the clinkering process of using CRC from a construction that suffered sulphate attack. It is difficult to find appropriate $\mathrm{SO}_{3}$ concentrations since a considerable scatter on the results is expected. The degradation process starts at the surface of the concrete by crack propagation, which is initiated by the formation of ettringite and other expansive products. The concentrations are thus depending on the ratio of the exposed surface to the concrete volume and the $\mathrm{SO}_{3}$ contents will be diluted in the concrete matrix.

In a study of the sulphate ingress in mortar samples produced with Portland cement, conducted by Schmidt et al. [3], the sulphate concentrations as a function of depth were studied. The effect of the sulphate ingress was observed up to about $5 \mathrm{~mm}$ for exposure times of 56 and 270 days. In that zone, the sulphate concentrations measured vary with the concentration of the sulphate solution and the exposure time. The $\mathrm{SO}_{3}$ concentrations varied from 5 to $20 \mathrm{wt} \%$ in case the mortar samples were exposed to a $44 \mathrm{~g} / 1 \mathrm{Na}_{2} \mathrm{SO}_{4}$ solution (high concentration). In Weritz et al. [4] different concrete cores obtained from sewage treatment plants that suffered sulphate attack were analysed for their sulphate content. Although the zones with affected sulphate concentrations were larger, up to $15 \mathrm{~mm}$, the measured sulphate concentrations were lower, up to $6 \mathrm{wt} \%$.

Different amounts of $\mathrm{CaSO}_{4}$ were added to CRC raw meals, before starting the laboratory clinkering process as described in 3.2. The studied range of sulphate content in the CRC raw meals was 1.6-5.3 wt\% (see Table 1). The chemical compositions of the produced raw meals and the regenerated clinkers are given in Table 1 and Table 2 respectively. In table 2 it is seen that a significant amount of $\mathrm{SO}_{3}$ is lost as gaseous emission in the clinkering process, as the measured $\mathrm{SO}_{3}$ content of the clinker is significantly lower compared to the expected $\mathrm{SO}_{3}$ content.

Table 1: Chemical composition of the produced CRC raw meals with different amounts of $\mathrm{CaSO}_{4}$ added (wt\%)

\begin{tabular}{|l|l|l|l|l|}
\hline Oxide & CRC 1.6 & CRC 1.9 & CRC 3.2 & CRC 5.3 \\
\hline $\mathrm{CaO}$ & 44.4 & 44.7 & 44.3 & 44.3 \\
\hline $\mathrm{SiO}_{2}$ & 14.1 & 14 & 13.7 & 13.0 \\
\hline $\mathrm{Al}_{2} \mathrm{O}_{3}$ & 3.3 & 3.0 & 3.0 & 2.9 \\
\hline $\mathrm{Fe}_{2} \mathrm{O}_{3}$ & 2.1 & 1.9 & 1.9 & 1.8 \\
\hline $\mathrm{MgO}$ & 1.3 & 1.2 & 1.2 & 1.2 \\
\hline $\mathrm{Na}_{2} \mathrm{O}$ & 0.08 & 0.06 & 0.07 & 0.06 \\
\hline $\mathrm{K}_{2} \mathrm{O}$ & 0.42 & 0.39 & 0.39 & 0.37 \\
\hline $\mathrm{SO}_{3}$ & $\mathbf{1 . 6}$ & $\mathbf{1 . 9}$ & $\mathbf{3 . 2}$ & $\mathbf{5 . 3}$ \\
\hline $\mathrm{Cl}^{-}$ & 0.018 & 0.045 & 0.016 & 0.017 \\
\hline $\mathrm{LOI}^{*}$ & 31.8 & 32.2 & 31.2 & 30.2 \\
\hline
\end{tabular}

$*$ LOI $=$ Loss On Ignition

Table 2: Chemical composition of the regenerated clinkers with different amounts of $\mathrm{CaSO}_{4}$ added (wt\%)

\begin{tabular}{|l|l|l|l|l|}
\hline Oxide & CRC 1.6 & CRC 1.9 & CRC 3.2 & CRC 5.3 \\
\hline $\mathrm{CaO}^{a}$ & 65.1 & 65.9 & 64.4 & 63.5 \\
\hline $\mathrm{SiO}_{2}$ & 21.6 & 21.5 & 21.1 & 19.8 \\
\hline $\mathrm{Al}_{2} \mathrm{O}_{3}$ & 4.7 & 4.1 & 4.3 & 4.2 \\
\hline $\mathrm{Fe}_{2} \mathrm{O}_{3}$ & 3.3 & 2.8 & 2.9 & 2.9 \\
\hline $\mathrm{MgO}$ & 1.9 & 1.8 & 1.8 & 1.8 \\
\hline $\mathrm{Na}_{2} \mathrm{O}$ & 0.11 & 0.09 & 0.11 & 0.11 \\
\hline $\mathrm{K}_{2} \mathrm{O}$ & 0.26 & 0.28 & 0.38 & 0.41 \\
\hline $\mathrm{SO}_{3}$ & $\mathbf{0 . 9}$ & $\mathbf{1 . 1}$ & $\mathbf{2 . 0}$ & $\mathbf{4 . 4}$ \\
\hline $\mathrm{Cl}^{-}$ & $<0.005$ & $<0.005$ & $<0.005$ & $<0.005$ \\
\hline $\mathbf{E x p}_{.}$ & $\mathbf{2 . 3}$ & $\mathbf{2 . 9}$ & $\mathbf{4 . 7}$ & $\mathbf{7 . 6}$ \\
$\mathrm{SO}_{3}{ }^{*}$ & & & & \\
\hline
\end{tabular}

${ }^{\mathrm{a}}$ The $\mathrm{CaO}$ contents were calculated from the raw material composition by exclusion of the LOI

Expected $\mathrm{SO}_{3}$ content, calculated from the raw material sulphate content by exclusion of the LOI

\subsection{The Cement Regeneration Process}

CRC rubble from compressive strength tests was used for the preparation of the cement raw meal. Before grinding the concrete in a planetary ball mill, it was broken in a jaw crusher (resulting particle size $<10 \mathrm{~mm}$ ). After 3 minutes milling of the cement raw meal at $300 \mathrm{rpm}$, the $\mathrm{CaSO}_{4}$ was 
added. The adapted raw meal was subsequently milled for 1 minute and the resulting powders were mixed with water to form a paste that was brought into a perforated PVC-plate. By drying, at least 1 day at room temperature or 2 hours at $60{ }^{\circ} \mathrm{C}$, small tablets $(\mathrm{d}=5 \mathrm{~mm}, \mathrm{~h}=5 \mathrm{~mm})$ were formed. After removing the tablets from the perforated plate, a raw meal was ready to be sintered.

A high temperature electric furnace (Carbolite BLF 1800) was used for simulating the burning process. The raw meals were gradually $\left(10{ }^{\circ} \mathrm{C} / \mathrm{min}\right)$ heated up to $1450{ }^{\circ} \mathrm{C}$ followed by a dwell time of $60 \mathrm{~min}$. After burning, the clinkers were immediately air-cooled by removal from the furnace.

\subsection{XRD Analysis}

The fired clinkers were prepared for XRD analysis by crushing the pellets to pass a $500 \mu \mathrm{m}$ sieve in a mortar and
Figure 1: Observed XRD patterns of the SAM extractions obtained from the $\mathrm{CRC}$ clinker with varying $\mathrm{SO}_{3}$ contents pestle, followed by fine grinding in a water-free ethanol medium in a planetary ball mill to reduce the clinker particle size distribution below a $\mathrm{d}_{50}$ of $10 \mu \mathrm{m}$. The ethanol grinding medium was immediately evaporated in a rotary evaporator to minimize carbonation of the suspended clinker powder. The XRD data were collected on a Thermo Scientific ARL X'tra Diffractometer equipped with a Peltier cooled detector.

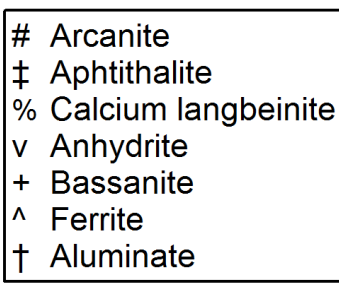

CRC 5.3
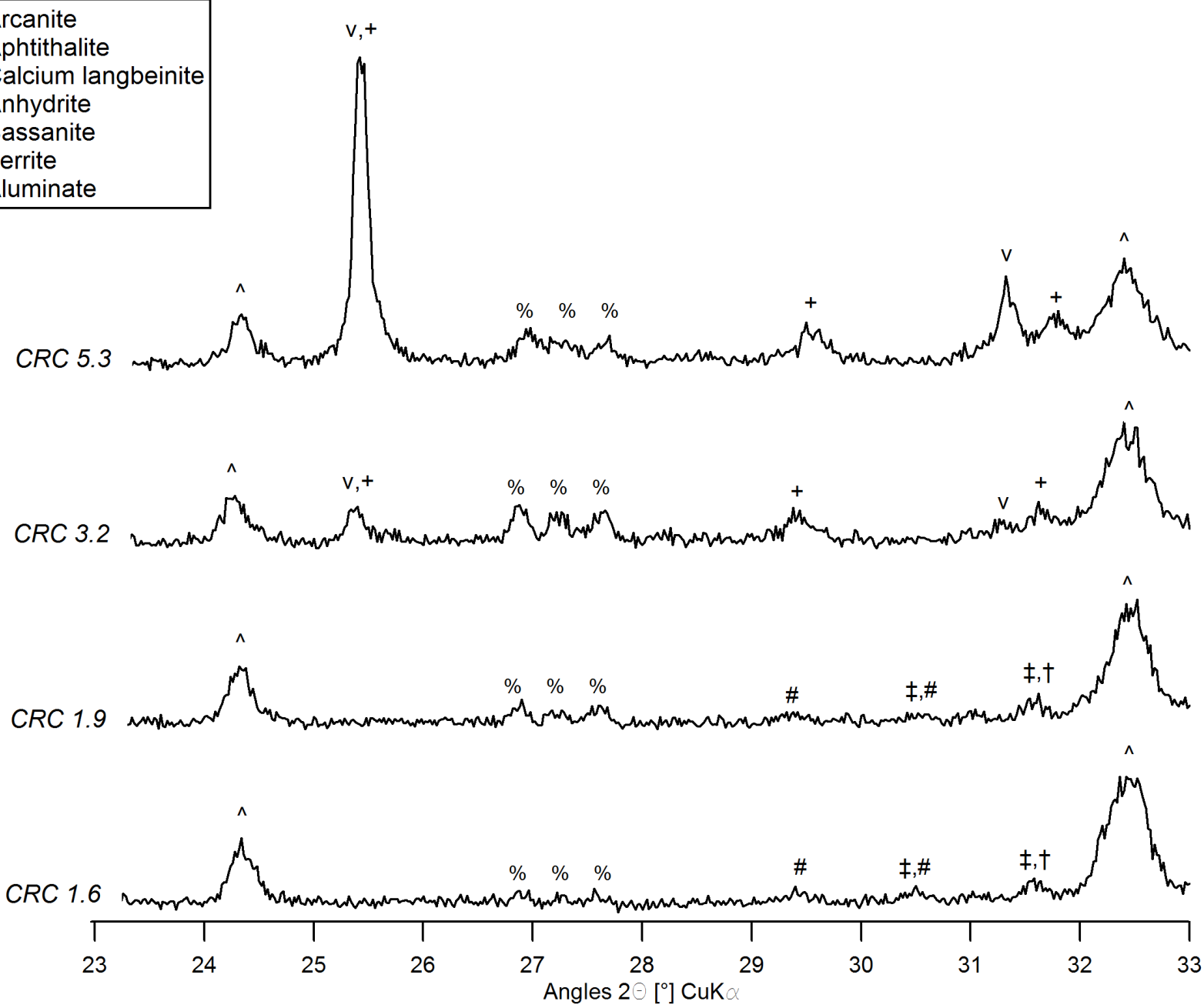

To increase the accuracy and lower the detection limits of the quantitative phase analysis by XRD, selective dissolution methods were used to reduce reflection peak overlap in the XRD patterns and concentrate the characteristic residue fraction. A solution of salicylic acid in methanol (SAM extraction) was used to dissolve the clinker calcium silicates and a solution of $\mathrm{KOH}$ and sucrose in $\mathrm{H}_{2} \mathrm{O}$
(KOSH extraction) to remove mainly the $\mathrm{C}_{3} \mathrm{~A}, \mathrm{C}_{4} \mathrm{AF}$ and soluble sulphate phases. The dissolution procedures are described elsewhere [5]. Additionally, the internal standard approach was selected for absolute phase quantification and estimation of the amorphous or non-identified phase content by XRD analysis [6, 7]. A $10 \mathrm{wt} \% \mathrm{ZnO}$ internal standard was added to the untreated clinker powder. Finally the 
powders were side-loaded into sample holders to reduce preferred orientation effects.

Samples were measured in $\theta-2 \theta$ geometry over an angular range of $5-70{ }^{\circ} 2 \theta$ ( $\mathrm{CuK} \alpha$ radiation) using a $0.02{ }^{\circ} 2 \theta$ step size and $1 \mathrm{~s} / \mathrm{step}$ counting time. Topas Academic V4.1 software was used for Rietveld refinement [8]. The phase quantification routine for the fired clinkers initiated with the identification of major and minor phases in the SAM and KOSH treated samples. Subsequently, peak shape and unit cell parameters of the major clinker phases were refined and used as fixed input for the final quantitative phase analysis of the untreated clinker samples as described in Le Saoût et al. [9]. Also the clinker $\mathrm{C}_{3} \mathrm{~A} / \mathrm{C}_{4} \mathrm{AF}$ weight ratio was taken from the analysis of the SAM treated residue. This procedure strongly reduces parameter correlation during refinement of the untreated sample. Overall, the refined parameters were the measurement specific or global zero error and cosine Chebyshev function of 12 polynomial terms and the phase specific scale factors, unit cell parameters and Lorentzian peak shape broadening parameters.

\section{RESULTS}

The effect of the sulphate additions on the clinker mineralogy was studied by XRD/Rietveld analysis. The XRD/Rietveld analysis of the SAM extraction was used to evaluate the distribution of the sulphate phases qualitatively. Quantitative analysis from XRD/Rietveld analysis of the whole clinker was not possible for all sulphate phases due to their presence under the detection limits related to their low concentrations. The effect of sulphate additions on the major phases was studied quantitatively by XRD/Rietveld analysis of the whole clinker sample.

\subsection{Distribution of the Sulphate Phases}

The XRD patterns obtained from the SAM extractions are shown in Figure 1. For the lower sulphate concentrations (CRC 1.6 and CRC 1.9), limited amounts of sulphates are found, namely arcanite and Ca-langbeinite. For higher sulphate concentrations (CRC 3.2 and CRC 5.3), significant amounts of the calcium sulphate anhydrite were observed. Some $\mathrm{H}_{2} \mathrm{O}$ bearing calcium sulphate phases (bassanite $\left.\left(\mathrm{CaSO}_{4} \cdot{ }_{1}{ }_{2} \mathrm{H}_{2} \mathrm{O}\right)\right)$ were observed. The uptake of this water probably occurred during the sample preparation. No thenardite, and only a limited amount of aphthitalite was found present in the CRC clinkers. The absence of significant amounts of sodium sulphates can be expected due to the low sodium concentrations of the clinkers.

For both calcium langbeinite and bassanite, the reflections slightly shift in the $2 \theta$ range. Rietveld analysis of the XRD patterns indeed showed that the cell parameters of both phases are affected by the sulphate concentration of the clinker. Probably the sulphate concentration slightly affects the composition of the phases and thus the cell parameters. In case of bassanite also the water content might be responsible for the observed shift.

\subsection{Effect on the Major Clinker Phases}

The results of the XRD/Rietveld analysis of the whole clinker samples are presented in Table 3. The formation of alite seems to be stimulated by a lower viscosity of the melt when the sulphate concentration was about $1.1 \%$ (CRC 1.9). A further increase of the sulphate concentrations resulted in the stabilisation of belite due to the uptake of $\mathrm{SO}_{3}$.

Table 3: Mineralogical composition of the regenerated clinkers with different amounts of $\mathrm{CaSO}_{4}$ added [wt $\%$ ] by XRD/Rietveld analysis

\begin{tabular}{|l|l|l|l|l|}
\hline Mineral & CRC 1.6 & CRC 1.9 & CRC 3.2 & CRC 5.3 \\
\hline Alite & 65.6 & 71.2 & 67.2 & 60.7 \\
\hline Belite & 16.3 & 11.2 & 21.7 & 22.9 \\
\hline Aluminate & 1.3 & 1.1 & 1.0 & 0.8 \\
\hline Ferrite & 11.5 & 9.7 & 9.2 & 9.4 \\
\hline Anhydrite & & & & 4.2 \\
\hline Calcite & 0.7 & 0.7 & 0.8 & 1.4 \\
\hline Periclase & 0.4 & 0.1 & 0.1 & 0.6 \\
\hline Other & 4.3 & 6.1 & & \\
\hline
\end{tabular}

In Table 4, the distribution of the four main clinker phases obtained by XRD/Rietveld analysis are compared with the potential mineralogy as calculated with the modified Bogue formulas. The increased amount of alite observed for CRC 1.9 is also obtained within the modified Bogue calculations. Since these calculations do not take into account the effect of alkali and/or sulphates on the viscosity of the melt and thus the burnability of the clinker, the increased alite content might be a result of rather limited changes in raw meal composition. In the end it is probably a combined effect of $\mathrm{SO}_{3}$ on the melt viscosity and the raw meal composition that explains the increased alite content in the clinker. The stabilisation of belite by the incorporation of $\mathrm{SO}_{3}$ is taken into account in the modified Bogue calculation. This effect is seen in the calculations for the CRC clinkers with the highest $\mathrm{SO}_{3}$ concentration (CRC 3.2 and CRC 5.3), having a significantly higher belite content at the expense of alite.

Table 4: Mineralogical composition of the regenerated clinkers with different amounts of $\mathrm{CaSO}_{4}$ added [wt\%] by XRD/Rietveld analysis

\begin{tabular}{|l|l|l|l|l|}
\hline Mineral & CRC 1.6 & CRC 1.9 & CRC 3.2 & CRC 5.3 \\
\hline XRD - normalized for four main clinker phases \\
\hline Alite & 69.3 & 76.5 & 67.8 & 64.8 \\
\hline Belite & 17.2 & 12.0 & 21.9 & 24.5 \\
\hline Aluminate & 1.3 & 1.1 & 1.0 & 0.8 \\
\hline Ferrite & 12.1 & 10.4 & 9.3 & 0.8 \\
\hline Modified Bogue - normalized for four main clinker phases \\
\hline Alite & 73.9 & 82.7 & 74.3 & 62.1 \\
\hline Belite & 10.2 & 3.6 & 10.7 & 20.9 \\
\hline Aluminate & 5.0 & 4.5 & 5.4 & 6.8 \\
\hline Ferrite & 10.9 & 9.2 & 9.5 & 10.1 \\
\hline
\end{tabular}

\section{DISCUSSION}

From literature it was concluded that the effect of an increasing sulphate content is highly depending on the alkali 
content. Since the alkali content of the studied clinkers is rather low, it was observed that an increasing sulphate content resulted in the formation of more $\mathrm{CaO}$ containing sulphates such as calcium langbeinite and anhydrite. The reasoning could be made that the consumption of $\mathrm{CaO}$ by the formation of calcium langbeinite and anhydrite will reduce the alite formation since less $\mathrm{CaO}$ is available. The latter is however not expected in this study, as the sulphates are added as calcium sulphate. Since a significant amount of sulphate was lost due to emissions in the clinkering process, a limited enrichment of the $\mathrm{CaO}$ content is more likely.

The experimental results obtained in the present study (low alkali content) showed that the effect of $\mathrm{SO}_{3}$ concentrations up to $2 \%$ on the clinker mineralogy are limited. For sulphate concentrations up to $4.4 \%$, the high $\mathrm{SO}_{3}$ content seemed to stabilize belite at the expense of alite. This effect is certainly not favoured, although the resulting alite contents are certainly acceptable for a modern clinker, since the alite content of the clinker to start from was rather high.

In practice, the sulphate content of a clinker raw meal should be limited in order to avoid clogging of material on the sides of the clinker kiln. Depending on the kiln installation, the sulphate content of the final clinker should be limited to $1.1-1.4 \%$ [10]. These more strict practical limitations will also avoid problems related to mineralogy as discussed above. Additionally, in practice, a stoichiometric balance is imposed on the sulphate and alkali content, expressed as the Degree of Sulphatisation (DoS) [10]:

$$
\operatorname{DoS}=\frac{77.41 \cdot w t \%\left(\mathrm{SO}_{3}\right)}{\left(w t \%\left(\mathrm{Na}_{2} \mathrm{O}\right)+0.658 \cdot w t\left(\mathrm{~K}_{2} \mathrm{O}\right)\right.}
$$

calculated using the chemical analysis of the final clinker. DoS levels between 80 and $120 \mathrm{wt} \%$ are recommended to avoid damage to the kiln system. In case of the current study, the alkali contents are rather low, resulting in an imbalance between the sulphates and alkali. In order to meet practical requirements, the $\mathrm{SO}_{3}$ and alkali content should thus be decreased or increased respectively.

Finally, it should be noted that the behaviour of alkalis and sulphates in the real clinkering process could not be simulated in the static furnace used. This study only showed how an increasing sulphate content (with constant alkali content) affects the clinker mineralogy. The effect of an increasing sulphate content of a cement raw meal on the clinker processing of a real kiln is expected to result in more strict limitations. An optimisation of the $\mathrm{SO}_{3} /\left(\mathrm{K}_{2} \mathrm{O}+\mathrm{Na}_{2} \mathrm{O}\right)$ balance in case of the studied CRC raw meals will be required. In the end it can be concluded that the use of concrete that suffered sulphate attack will not harm the clinkering process, if properly diluted.

\section{CONCLUSION}

When using CRC as cement raw material, the permeated acids and salts in deteriorated concrete will have an effect on the clinkering process. In this study the effect of sulphate additions to a CRC raw meal on the regenerated clinker mineralogy was studied by means of XRD/Rietveld analysis. It was found that an increasing sulphate content stimulates the formation of $\mathrm{CaO}$ containing sulphates such as calcium langbeinite and anhydrite. Additionally it was found that higher sulphate concentrations stabilize belite at the expense of alite.

\section{ACKNOWLEDGEMENTS}

Financial support from the Institute for the Promotion of Innovation through Science and Technology in Flanders (IWT-Vlaanderen) and the Research Foundation - Flanders (FWO) under Grant no. G087510N are gratefully acknowledged. The authors would like to thank P. Van der Voort for granting access to the XRD facilities.

\section{REFERENCES}

[1]. Glasser FP. Advances in Cement Clinkering. In: Bhatty J.I., Miller F.M.G., Kosmatka S.H., editors. Innovations in Portland Cement Manufacturing. Skokie, IL: Portland Cement Association; 2004. p. 331-68.

[2]. Jawed I, Skalny J. Alkalies in cement: A review I. Forms of Alkalies and their effect on clinker formation. Cement Concrete Res. 1977;7:719-29.

[3]. Schmidt T, Lothenbach B, Romer M, Neuenschwander J, Scrivener K. Physical and microstructural aspects of sulfate attack on ordinary and limestone blended Portland cements. Cement Concrete Res. 2009;39:1111-21.

[4]. Weritz F, Taffe A, Schaurich D, Wilsch G. Detailed depth profiles of sulfate ingress into concrete measured with laser induced breakdown spectroscopy. Construction and Building Materials. 2009;23:275-83.

[5] Gutteridge WA. On the dissolution of the interstitial phases in Portland cement. Cement Concrete Res. 1979;9:319-24.

[6]. Bish DL, Howard SA. Quantitative phase analysis using the Rietveld method. Journal of Applied Crystallography. 1988;21:86-91.

[7]. Martín-Márquez J, De la Torre AG, Aranda MAG, Rincón JM, Romero M. Evolution with Temperature of Crystalline and Amorphous Phases in Porcelain Stoneware. Journal of the American Ceramic Society. 2009;92:229-34.

[8]. Coelho AA. Topas Academic version 4.1. 2007.

[9]. Le Saoût G, Kocaba V, Scrivener K. Application of the Rietveld method to the analysis of anhydrous cement. Cement Concrete Res. 2011;41:133-48.

[10]. Schoon J, Van der Heyden L, Eloy P, Gaigneux EM, De Buysser K, Van Driessche I, De Belie N. Waste fibrecement: An interesting alternative raw material for a sustainable Portland clinker production. Construction and Building Materials. 2012;36:391-403 


\section{BIOGRAPHIES}

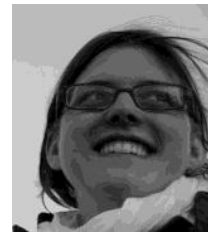

University).

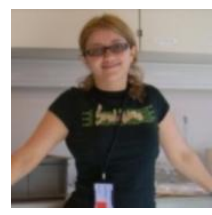

Eleni C. Arvaniti received her $\mathrm{PhD}$ degree from the University of Patras (Greece) in 2009. From May 2012 until April 2014 she was working as a post-doctoral researcher on Completely Recyclable Concrete at the Magnel laboratory for Concrete Research (Ghent University). degree in civil engineering in 2009 from Ghent University (Belgium). Currently she is finishing her $\mathrm{PhD}$ on Completely Recyclable Concrete at the Magnel laboratory for Concrete Research (Ghent

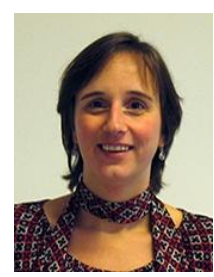

Klaartje De Buysser received her $\mathrm{PhD}$ degree from Ghent University (Belgium) in 2007. Since 2009 she is professor at the faculty of science at Ghent University (SCRiPTS research group). Her research interests are transparent, conductive oxides, thermoelectric materials and electrospinning of ceramic fibres.

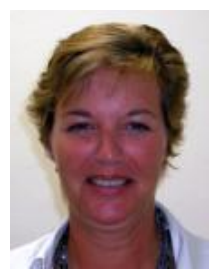

Isabel Van Driessche is professor at Ghent University (Belgium) since 2004. She is head of the department Inorganic and Physical Chemistry and leads the research group SCRiPTS, that has activities in the broad field of solid state chemistry related to the synthesis, properties and applications of inorganic and ceramic materials, both as bulk and thin films.

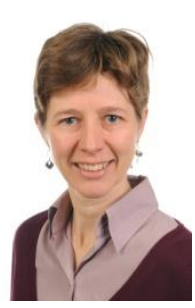

Nele De Belie is professor in Durability of Cement Bound Materials at Ghent University (UGent) since 2000. She is technical director of the Magnel Laboratory for Concrete Research and leads the research group Concrete and Environment that has activities in the broad field of cement and concrete related to durability and sustainability. 